\title{
Resource windfalls, fiscal effort and public spending: evidence from Brazilian municipalities
}

\author{
Fernando Antonio Slaibe Postali \\ Fabiana Rocha \\ Departamento de Economia, FEA-USP
}

\begin{abstract}
:
In 1997, Brazil approved a new law establishing the regulatory framework of oil and gas industry. One of the most important changes was the distribution of petroleum rents to states and Municipalities. The volume received by each municipality varies considerably, since it depends on a range of criteria that measure the impact of upstream activities on the specific municipality as well as the number of productive wells next to it. This paper aims at evaluating whether municipalities eligible to receive royalties exhibited a lower fiscal effort than the non-eligible ones. We use the local collection of Urban Property Tax (IPTU) as a measure of fiscal effort, after controlling for fiscal capacity of each municipality. We also assess whether municipalities are obeying requirements of spending oil rents, by measuring the impact of such rents on specific items of the budget, like personal, health, education and investment expenses. The data set comprehends about 4000 municipalities observed during seven years (from 1999 to 2005). We used the Arellano-Bond GMM estimator in a dynamic panel with fixed effects. Results allow concluding that windfall oil rents in fact reduces fiscal effort and increases the allocation of budgetary resources on investment, but the share of budget allocated on health, education, energy and housing expenses did not changed as consequence of oil royalties.
\end{abstract}

Keywords: fiscal federalism, windfall oil rents, fiscal effort, public spending.

JEL Classification: H71, H75.

Resumo:

Em 1997, o Brasil aprovou nova lei que estabelece o marco regulatório da indústria petrolífera e do gás. Foram estabelecidos novos critérios de distribuição de rendas do petróleo para os Estados e Municípios. O volume recebido por cada município varia consideravelmente, uma vez que depende de uma série de critérios que medem o impacto das atividades de produção de petróleo sobre o Município, bem como o número de poços adjacentes. Este trabalho visa avaliar se os municípios beneficiados com royalties apresentam um esforço fiscal menor que os não-beneficiados. Usamos a receita local de IPTU como uma medida do esforço fiscal, após o controlar pela capacidade fiscal de cada município. Também avalia se os municípios estão cumprindo exigências de gastos de recursos do petróleo, medindo o impacto de tais rendas sobre itens específicos do orçamento, como despesas de pessoal, saúde, educação e investimento. $\mathrm{O}$ conjunto de dados compreende cerca de 4.000 municípios observados durante sete anos (de 1999 a 2005). Utilizamos o estimador de Arellano-Bond em um painel dinâmico de efeitos fixos. Os resultados permitem concluir que as rendas petrolíferas reduzem esforço fiscal e aumentam a alocação dos recursos orçamentários em investimento, mas a fração do orçamento destinado à saúde, educação, energia e habitação despesas não mudou como conseqüência de royalties do petróleo.

Palavras-chave: federalismo fiscal, rendas petrolíferas, esforço fiscal, despesa pública. JEL: H71, H75.

Área 4: Economia do Setor Público. 


\section{Introduction}

In the 1990s Brazil reformed the regulatory benchmark of its oil and gas industry. The approval of the law 9478/97 implied that a portion of petroleum rent should be shared with producer municipalities in a new basis: all concessionaires must pay royalties to the government, with $10 \%$ ad valorem tax over the gross value of production. After 1997, this tax base started to be calculated based on international prices, instead of refining prices as before after collecting royalties, the Federal Treasury distributes them to a selected set of states and Municipalities that fulfill some criteria regarding the production and transportation of oil.

The law benefited about 800 municipalities (among the universe of 5500). The volume received by each municipality varies considerably, since it depends on a range of criteria that measure the impact of upstream activities on the specific municipality as well as the number of productive wells next to it. The law obligates the municipalities to invest royalties in specific items, the most part of them linked to investment in infrastructure.

The argument for municipalities to receive additional financial revenues would be that this is a way to compensate them for the oil exploitation in their territories or neighboring areas.

Such revenues are classified as intergovernmental transfers since the resources belong to the Union that transfers them to sub national governments. These transfers are mandatory, unconditional and without exchange, and dependent on the local oil production. The Union is obligated to make the transfer as constitutional requirement. The Municipality has some freedom to allocate resources and is not required to supplement the funds received.

The key role of financial compensation is to make compatible intergenerational interests (Friedmann and Montalvão, 2003; Serra, 2003). Since oil is a finite resource, its use today turns it impossible to be extracted any time in the future. Thus, the imposition of financial compensation would charge the extraction with an additional cost, reducing its production relative to the optimum and allowing future generations to access to income generated by this natural resource. Furthermore, the additional revenue arising from the compensation should be invested in durable assets (infrastructure, environmental preservation) that can be enjoyed by future generations, compensating them in part by the previous consumption of non-renewable resources (Hartwick, 1977).

The problem is that the municipalities where the extractive activity occurs should be exactly offset by the costs they incur to support the extraction of oil, as construction of drainage channels for the production, provision of public services for exploratory businesses and its employees, etc., and one additional for future investment in assets. In practice, however, transfers go far beyond that. Some municipalities receive amounts representing significant fraction of their ordinary revenues. The table 1 illustrates the dependence of some municipalities within the two most benefited Brazilian states in 2005. Some municipalities have almost half of its revenue budget linked to oil royalties. 
Table 1: Mean of royalties-budgetary revenue in 2005, by state

\begin{tabular}{lccccc}
\hline State & $\begin{array}{c}\text { Eligible } \\
\text { Districts }\end{array}$ & Mean & $\begin{array}{c}\text { Standard } \\
\text { Deviation }\end{array}$ & Min & Max \\
\hline Rio de Janeiro & 46 & $14.60 \%$ & $11.08 \%$ & $0.57 \%$ & $43.97 \%$ \\
Rio Grande do Norte & 60 & $3.50 \%$ & $7.44 \%$ & $0.40 \%$ & $47.19 \%$ \\
\hline \multicolumn{4}{c}{ Source: ANP and National Treasury. Considering only eligible districts. }
\end{tabular}

It is believed that this windfall revenue due to royalty transfers led to (i) implementation of public projects with low marginal social return; (ii) reduction of tax effort; (iii) corruption; (iv) inefficiency.

The purpose of this paper is to investigate the effects of large fiscal windfalls operating through the government. More precisely, we evaluate whether municipalities eligible to receive royalties exhibit different fiscal behavior when compared to noneligible ones in two ways: lower fiscal effort and high level of expenditures and investment.

We use the local collection of property tax - IPTU- as a measure of fiscal effort, and expenditures on various budgetary items, after controlling for fiscal capacity of each municipality. The data set comprehends budgetary data from 4000 municipalities observed during seven years (from 1999 to 2005). With the purpose of controlling for possible endogenous effects of transfers, we use the Arellano-Bond estimator. Results allow us to conclude that the higher the volume of received royalties, the lower the revenues of taxes associated to collection effort, the lower current spending and the higher the investment.

This issue is highly relevant given the announcement of the new exploratory frontier in the pre-salt layer of the ocean in 2008. The new reserves can increase substantially petroleum rents in the hands of municipalities in the next years, and an adequate understanding of the fiscal behavior on impacted cities can contribute to design better rules for the optimum use of such revenues by local governments.

The paper is organized as follows: section 2 presents an overview on the new regulatory environment of oil industry in Brazil as well as some remarks about the fiscal federalism and the rationale for sharing oil rents with federative entities; section 3 describes the data set and some descriptive statistics; section 4 presents the model to assess evidence of low fiscal effort on benefited districts and comment its results; section 5 presents the model to assess the impact of royalty revenues on some component of Municipal spending and the results; the last section brings some concluding remarks.

\section{Brazilian oil rents and fiscal federalism}

The Federal Government provides a subset of Brazilian municipalities with a financial compensation in the form of a percentage of collected petroleum rents (royalties) in order to offset possible deleterious effects of oil and gas production over their economies.

Federal Law 9478 of 1997 (the so-called "Petroleum Law) is the starting point of the new regulatory framework for the oil market, securing a significant portion of royalties for the municipalities affected by the oil and gas upstream sector. 
The law also introduced new rules to calculate royalties to be shared among eligible municipalities that meet specific criteria, like being directly or indirectly impacted by oil and gas upstream activities and/or being a producing area ${ }^{1}$.

Like many other countries, Brazil runs a special fiscal regime over oil and gas production. The most important tax is the 'Royalty', composed by a 10 percent-rate over the gross value of crude oil or gas production. Funds raised are shared among producing States and Municipalities, the National Treasury, the Secretariat of Science and Technology and the Navy. Municipalities impacted by the oil industry are also entitled to receive such revenues.

Besides royalties, another important tax is the Special Participation Fee. This modality is applied in a progressive basis over the net revenue of production and does not charge all projects, but only the most profitable ones. Funds collected through special participation are shared among states, producing Municipalities ${ }^{2}$, the Secretariat of Mining and Energy and the Secretariat of Environment and Natural Resources. ${ }^{3}$

The law 9478 also allowed municipalities to invest royalty funds in a larger number of projects, whereas the previous restricted considerably such possibilities (only investments in energy, environment and sewage were allowed). Under the rules from 1997, royalty funds cannot be allocated to debt management and payroll administration.

An important characteristic of the system is that petroleum royalties are calculated based on international prices (instead of domestic refining prices), which turns such revenues very sensitive to the oscillation of oil prices and exchange rates. The new law also enlarged significantly the set of municipalities eligible for receiving royalties. With the substantial climb in the international oil value after 1999 and the collapse of fixed exchange regime in Brazil in 1999, royalty revenues in the hands of local districts increased very strongly, as we can see in figure 1.

Figure 1: Royalty revenues and portion shared with Municipalities in Brazil, in billions of dollars ${ }^{4}$.

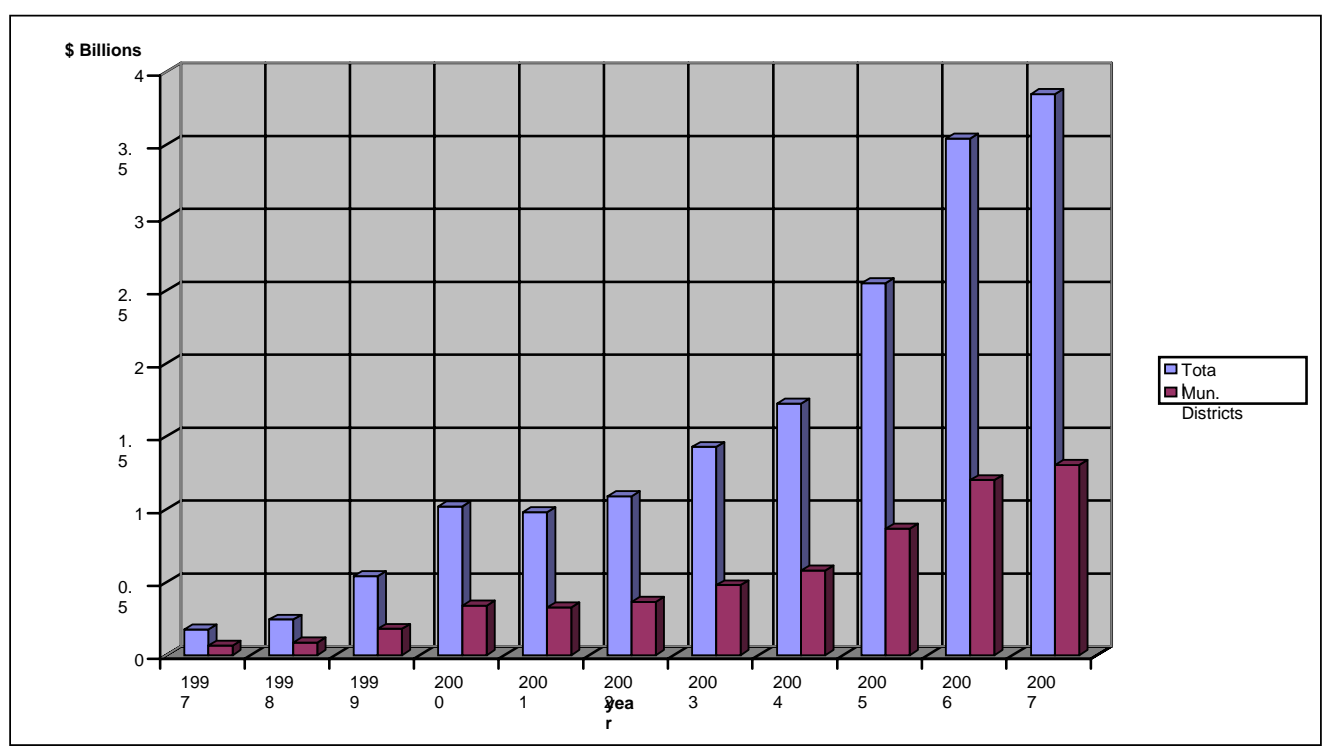

Source: National Petroleum Agency - ANP.

\footnotetext{
${ }^{1}$ The most part of the Brazilian oil production is extracted offshore. The characterization as a producing municipality depends on the projection of its territorial circumscription to the sea.

${ }^{2}$ About two dozens Municipalities receive Special Participation.

${ }^{3}$ Details about each tax are in the Presidential Decree 2.705/1998.

${ }^{4}$ Converted by the annual average exchange rate "Reais"/\$.
} 
There is a wide range of studies about the relationship among intergovernmental transfers, fiscal effort and expenditures in Brazil. Such studies gained momentum after the Constitution of 1988, which produced an incomplete decentralization (Reis and Blanco, 1996), that is, the expansion of the shares of municipal levels on tax resources without the corresponding increase in their costs and responsibilities for the expenses.

Shah (1994), in a study involving several emerging and developing countries, gathers evidence suggesting that transfers induce municipalities to under-use their own tax base. On the specific case of Brazil, the study concludes that the fiscal effort is not satisfactorily taken into account in the design of constitutional transfers, which ultimately benefit larger cities.

Blanco (1998) concludes that there is a negative relationship between the fiscal effort and intergovernmental transfers, since municipalities highly dependent on federal transfers tend to reduce their own effort to collect taxes. Ribeiro and Shikida (2000) reach the same conclusion for a sample of municipalities of the Minas Gerais state.

Reis and Blanco (1996) develop certain concepts of efficiency and tax capacity, presenting their determinants for each federative unit. Using the stochastic frontier method (Battese, 1992), the authors conclude that there is great disparity in tax efficiencies within the Brazilian states, resulting from huge differences in the degree of development across regions. From 1970 to 1990, they estimate that the average tax efficiency $^{5}$ of the Brazilian municipalities is around 0.83 , with an outstanding performance for Sao Paulo's municipalities (mean 0.93), the richest federative unit.

By building an index of tax effort, Ribeiro (2005) proposes a model to measure the impact of intergovernmental transfers on fiscal effort. His model assumes that fiscal effort is negatively related to intergovernmental transfers. However, the author founded positive relationship in some cities, which is explained as specific characteristics of these municipalities.

Focusing on the spending side, several empirical studies have shown that intergovernmental transfers have a greater effect on expenditure of cities receiving such transfers than a corresponding increase in income of its taxpayers. This is called flypaper effect. Inman (2008) and Gamkhar and Shah (2007) provide overviews of theoretical explanations and empirical evidences on the flypaper effect.

Inman (2008) discusses the origins and the theoretical development of the flypaper effect, listing four possible explanations for the phenomenon. The author rejects econometric-based explanations (omitted variable, problems of specification, incomplete data) and attributes the flypaper effect to political reasons and "contract failure" between voters and elected legislators. Also Dahlby (2009) presents theoretical considerations on flypaper effect, attributing it to the fact that local governments finance their spending with distorting taxes and the lump-sum transfers make possible to reduce the marginal cost of public funds, allowing supply public goods at a lower shadow cost.

\footnotetext{
${ }^{5}$ In a stochastic frontier model, the tax efficiency is estimated as the ratio between the variance of the technical efficiency $(u)$ and the variance of the model $(u+v)$.
} 
Using techniques of spatial econometrics, Cossio and Carvalho (2001) found evidence of flypaper effect in the Brazilian federal system, insofar as the constitutional transfers induce a raise in expenses in larger amounts than the increase in municipal GDP per capita.

Studies on the effects of royalties on the municipal finances are much more limited. The criteria governing the distribution of oil royalties in Brazil are not subject to the same logic than the fiscal federalism, as the reduction of regional inequalities (Dixit and Lodregan, 1998), sharing of risk and stabilization of idiosyncratic shocks (Persson and Tabellini, 1996). Oil rents, according to guidelines from law 9478, are shared with the localities following two principles: i) the municipality must be labeled as "producer", ii) the municipality must be directly or indirectly affected by activities of oil production.

The natural question emerging is whether Municipalities entitled to receive oil royalties have suffered the same effects of regular transfers in terms of fiscal efforts and budgetary expenses. Some studies have been investigating the impact of royalties on localities in Brazil after the Petroleum Law was enacted. Such studies have focused on social changes and fiscal behavior of eligible municipalities.

Leal and Serra (2002) studied the destination of royalty revenues in municipalities located in northern Rio de Janeiro State. They concluded that the volume of investments made by eligible municipalities was above that of the state's average, but the investment-royalties ratio is consistently below one.

Costa Nova (2005) examined various social indicators of some municipalities that received significant amounts of royalties in the state of Bahia to conclude that despite a relative surplus in the budget provided by royalty funds, such municipalities did not improve their social indicators significantly above the regional average.

Navarro (2003) published a detailed case study about the destination of royalty revenues in the city of Campos dos Goytacazes, state of Rio de Janeiro, the largest city benefiting from such resources in absolute values. His founds suggest that according to him, the Human Development Index evolved slightly above the regional average in the 1990s. Moreover, Campos dos Goytacazes has increased its investments in sewage and infrastructure, but at a lower pace than its increase in royalty rents.

Bregman (2007) studied the relationship among capital expenses, investments and degree of dependence on resource rents from 1999 to 2005. By estimating a pooled regression in municipalities grouped by the amount of received royalties, the author concludes that the most royalty-dependent municipalities increased their capital expenses in the same extent than the received revenue.

This paper aims at providing a more comprehensive study than the previous ones. With the purpose of controlling for possible endogenous effects of transfers, we employed dynamic panel-data with the Arellano-Bond estimator (Arellano and Bond, 1991), which consists in a GMM with a combination of lagged independent variables as instruments.

\section{The data}

The fiscal data were obtained from the National Treasury Secretary (STNFinbra) while the royalty revenues were get from the National Petroleum Agency 
(ANP). The data regarding Municipal GDP and population are from IBGE, the Brazilian Geography and Statistics Institute. The combination of these data sets resulted in a unbalanced panel ${ }^{6}$ composed by around 5,000 Municipalities from 1999 to 2005. Among those Municipalities, around 500 are eligible for receiving royalties due to the new law.

Table 2: Descriptive statistics, from 1999 to 2005.

\begin{tabular}{lccccc|ccccc}
\hline & \multicolumn{6}{c|}{ Eligible } & \multicolumn{5}{c}{ Non-eligible } \\
\hline & Obs & Mean & St. Dev. & Min & Max & Obs & Mean & Std. Dev. & Min & Max \\
Royalties & & & & & & & & & & 0 \\
Personal & 4103 & 2.93 & 7.52 & $7.9 \mathrm{E}-04$ & 67.94 & 38956 & 0 & 0 & 0 & 0 \\
Cost & 4103 & 56.54 & 14.3 & 0 & 98.54 & 38944 & 48.58 & 14.63 & 0 & 100 \\
Investment & 4103 & 80.12 & 10.2 & 22.45 & 99.8 & 38953 & 77.1 & 10.71 & 0 & 100 \\
IPTU per capita (R\$) & 4103 & 13.4 & 8.77 & 0 & 71.43 & 38953 & 13.13 & 8.82 & 0 & 92.35 \\
\hline
\end{tabular}

Source: Own elaboration, based on data from ANP and National Treasury. Royalties expressed relative to Municipal revenues, in \%; Personal expenses, cost expenses and investments are expressed relative to the budgetary spending, in \%.

Table 2 summarizes the descriptive statistics about the data. As one can see, the royalty-budgetary revenue ratio varies substantially across the eligible Municipalities ${ }^{7}$. On average, royalty beneficiaries have exhibited 2.93 of their budgetary revenues with such resources from 1999 to 2005. It is interesting to notice that the relative personal expenses are higher in eligible districts than in non-eligible ones (56.54\% against $48.58 \%$ ), while the average relative investment seems to be the same between both groups (around 13\%).

\section{Resource abundance and taxation}

As reported in the previous sections, the literature about fiscal federalism in Brazil brings evidence on reduced fiscal efficiency of Municipalities highly dependent on grants of federal government. With the purpose of investigating whether oil rents generate similar effects, we have estimated the following dynamic panel model:

$$
\begin{gathered}
\log \left(I P T U \_P C\right)_{i t}=\alpha_{i}+\delta \log \left(I P T U \_P C\right)_{i t-1}+\gamma E L I G i t \\
\beta_{2} \log \left(G D P \_P C\right)_{i t}+\beta_{3} \log \left(1+R O Y(P O P)_{i t}+\beta_{4} \log \left(F P M \_R E V\right)_{i t}+\beta_{5} \log \left(A G R \_G D P\right)_{i t}+\varepsilon_{i t}+\right.
\end{gathered}
$$

Where:

$I P T U_{-} P C_{i t}$ : the Property tax collection (IPTU) per capita of Municipality $i$ in year $t$;

$E L I G_{i t}$ : Dummy for eligible Municipality;

$R O Y \_R E V_{i t}$ : royalty-revenues ratio of Municipality $i$ in year $t$;

GDP_PC $i t$ : Municipal GDP per capita;

$P O P_{i t}$ : Population of Municipality $i$ in year $t$;

\footnotetext{
${ }^{6}$ The number of eligible municipalities in our dataset varies over years due to data availability.

${ }^{7}$ There is a discussion today in Brazil about the creation of fairer criteria for sharing royalties, since the current rules benefit much more a restricted set of municipalities over others.
} 
$F P M \_R E V_{i t}$ : Constitutional transfers ${ }^{8}$ to Municipality $i$ in year $t$ relative to the Municipal revenue;

AGR_GDP ${ }_{i t}$ : share of agricultural GDP on Municipal GDP.

$\alpha_{i}$ : fixed effect.

$\varepsilon_{i t}$ : White Noise.

The use of the Urban Property Tax per capita (IPTU_PC) as a measure of fiscal effort can be justified by the nature of this tax, whose collection depends not only on Municipal income, but also on aliquots and supervisory procedures. The lagged value is also added among the covariates in the dynamic model.

The degree of dependence of Municipal finance on oil rents is measure by the ratio between royalty revenues and the whole revenue (ROY_REV). Since the most part of Municipalities do not receive royalties, we took the log of the sum of this variable with 1 . The higher this ratio, the higher the Municipality's finance depend on oil rents.

The dummy ELIG aims to capture possible specificity of Municipalities entitled to receive oil rents through royalties under the 9478 law. Such Municipalities are considered oil producers or their economies are impacted by activities of the oil and gas industry. The dummy searches for possible different pattern of tax collection in producer (or impacted) localities.

GDP_PC aims to control for the fiscal capacity, since localities with high income per capita are able to collect more taxes from their taxpayers. The population (POP) controls for the size of each Municipality. The share of agricultural GDP over Municipal product is added to control for the tax base, since IPTU is urban tax that levies on urban properties and the responsibility for the collection belongs to the city hall.

OLS estimation of equation (1) leads to biased estimates of $\delta$ and $\beta$, because the lagged dependent variable induces a correlation the error and independent variables. Trying to overcome this problem, the coefficients were estimated by the Generalized Method of Moments (GMM) using the Arellano-Bond estimator (Arellano and Bond, 1991), which consists in employing the sequence of lagged variables as instruments. GMM also allows controlling for possible endogenous effects that can emerge from fiscal variables, since poor Municipalities, with reduced fiscal capacity, are firstly eligible to receive mandatory federal funds.

Table 3 summarizes the results. Specification 2 tries to control for political factors leading to fiscal effort, with dummies for the political party in the Municipal power each year. The estimated coefficients show that high levels of royalties induce lower collection of Urban Property Tax per capita: on average, 1\%-increase in royaltyrevenues ratio reduces the IPTU per capita in $1.34 \%$. Since the fiscal capacity is assumed to be controlled by income per capita, this result suggests that high level of royalties (relative to the budgetary revenue) leads to a decrease in fiscal effort. Estimates are robust to the inclusion of dummies for political party in charge.

\footnotetext{
${ }^{8}$ FPM: Fundo de Participação dos Municípios.
} 
Table 3: Results for Urban Property Tax (IPTU) per capita - Arellano and Bond

\begin{tabular}{|c|c|c|}
\hline \multicolumn{3}{|c|}{$\begin{array}{c}\text { Dependent variable: } \\
\text { log(IPTU per capita) }\end{array}$} \\
\hline $\begin{array}{l}\text { Independent } \\
\text { Variables (log) }\end{array}$ & (1) & (2) \\
\hline lag_1 & $\begin{array}{l}0.148^{* * *} \\
(0.029)\end{array}$ & $\begin{array}{l}0.151^{* * *} \\
(0.029)\end{array}$ \\
\hline$E L I G$ & $\begin{array}{c}0.143^{*} \\
(0.0788)\end{array}$ & $\begin{array}{l}0.144^{*} \\
(0.0787)\end{array}$ \\
\hline$R O Y \_R E V$ & $\begin{array}{l}-1.345^{* * *} \\
(0.0348)\end{array}$ & $\begin{array}{l}-1.347^{* * *} \\
(0.0339)\end{array}$ \\
\hline$G D P \_P C$ & $\begin{array}{c}0.0466 \\
(0.0306)\end{array}$ & $\begin{array}{c}0.0474 \\
(0.0307)\end{array}$ \\
\hline POP & $\begin{array}{l}-1.127^{* * *} \\
(0.159)\end{array}$ & $\begin{array}{l}-1.140^{* * *} \\
(0.159)\end{array}$ \\
\hline$F P M \_R E V$ & $\begin{array}{c}-0.0092 \\
(0.0124)\end{array}$ & $\begin{array}{c}-0.0092 \\
(0.0124)\end{array}$ \\
\hline$A G R \_G D P$ & $\begin{array}{c}0.0118 \\
(0.0210)\end{array}$ & $\begin{array}{c}0.0126 \\
(0.0211)\end{array}$ \\
\hline Constant & $\begin{array}{l}11.75^{* * *} \\
(1.504)\end{array}$ & $\begin{array}{l}10.94^{* * *} \\
(1.521)\end{array}$ \\
\hline Year dummy & Yes & Yes \\
\hline $\begin{array}{l}\text { Political party } \\
\text { dummy }\end{array}$ & No & Yes \\
\hline Obs. & 18141 & 18119 \\
\hline Panel & 4621 & 4615 \\
\hline chi2 & 3597 & 3937 \\
\hline sig2 & 0.286 & 0.286 \\
\hline
\end{tabular}

\section{Resource abundance and spending}

The question that remains to be answered is how local governments spend the money brought by oil.

The political -economy literature identifies two mechanisms through which resource abundance may affect spending that are particularly interesting for the Brazilian case.

The first one concerns the increased motivation to create government jobs to reward political supporters that results from the sudden increase in oil royalties (Robinson, Torvik and Verdier, 2002). The result would be a decline in labor supply and an increase in government employment.

The second one concerns the decrease on the supply of public infrastructure that may follow the resource windfall. The larger amount of resources available to the 
incumbent government due to the resource windfalls makes the desire to remain in power higher. At the same time, the outside pressure for the position also increases. The result is a reduction in the planning horizon of the incumbents. If it takes some time to infrastructure provide public and/or private benefits, the result is a reduction in its provision (Caselli, 2007).

The point is that the "Petroleum law" obligates the municipalities to invest the most part of its royalties in infrastructure. This fiscal rule has been adopted, as discussed before, to minimize the negative externalities for future generations due to resource exploitation, and if the rule is enforceable, it should imply an increase in infrastructure. ${ }^{9}$

In order to test the effect of royalties on relative spending, we regress cost spending relative to budget, personal spending relative to budget and investment spending on royalties revenues and other control variables. Since we do not have data on number of employees we use current spending and personal spending instead.

$$
\begin{aligned}
\log \left(S P E \_B U D\right)_{i t}= & \delta \log \left(S P E \_B U D\right)_{i t-1}+\gamma E L I G_{i t}+\beta_{1} \log \left(1+R O Y \_R E V\right)_{i t}+ \\
\beta_{2} \log \left(G D P \_P C\right) & \beta_{3} \log (P O P)_{i t}+\beta_{4} \log \left(F P M \_R E V\right)_{i t}+\beta_{5} \log \left(A G R \_G D P\right)_{i t}+ \\
& \beta_{6} \log \left(R E V \_G D P\right)+\varepsilon_{i t}
\end{aligned}
$$

where $S P E \_B U D$ is the spending to budget ratio, is the REV_GDP is the budgetary revenue relative to the Municipal GDP. This aims to control for the size of each Municipal government.

We initially run the regressions using as the dependent variable: cost, personal, and investment spending. Then we repeat the regressions using health, education, energy, and housing spending.

The analysis of such types of spending is justified not only by the assumed effects of windfall revenues on the behavior of Municipal managers, but also because the Petroleum Law establishes guidelines for applying such rents. The oil royalties must be invested in infrastructure and the use of such resources to debt management and payroll is forbidden by the Courts of Auditors. Therefore, the result is very important to infer whether the law is enforceable, leading the municipalities to apply royalty revenues properly; if this is the case, we should observe a positive effect of royalties on investment and infrastructure spending, and a negative effect on cost and personal spending.

All dependent variables were calculated relative to their national averages each year. The purpose of this device is to isolate local shocks from national macroeconomic shocks that affect the finance of all Municipalities. Therefore, each variable is above or below one whether is above or below the national average.

As previously, we have adopted the Arellano-Bond estimator, with the purpose of dealing with the potential bias of estimator.

\footnotetext{
${ }^{9}$ Here a fiscal rule is understood in a narrow way. It is "a statutory or constitutional restriction on fiscal policy that sets a specific limit on a fiscal indicator such as the budgetary balance, debt, spending, or taxation. In other words, the focus is restricted to rules that impose a specific, binding constraint on the government's range of policy options” (Kennedy and Robbins , 2001, p. 2).
} 
Table 4: Results for spending: Cost, Personal and Investment

\begin{tabular}{|c|c|c|c|c|c|c|}
\hline \multirow[b]{2}{*}{ Independent variables (log) } & \multicolumn{6}{|c|}{ Dependent Variables, relative to budgetary expenses, in log. } \\
\hline & $\begin{array}{l}\text { Cost } \\
(1 . a) \\
\end{array}$ & $\begin{array}{c}\text { Personal } \\
(2 . a) \\
\end{array}$ & $\begin{array}{c}\text { Investment } \\
\text { (3.a) }\end{array}$ & $\begin{array}{l}\text { Cost } \\
(1 . b) \\
\end{array}$ & $\begin{array}{c}\text { Personal } \\
(2 . b) \\
\end{array}$ & $\begin{array}{c}\text { Investment } \\
\text { (3.b) }\end{array}$ \\
\hline Lag_1 & $\begin{array}{l}0.246^{* * *} \\
(0.024)\end{array}$ & $\begin{array}{l}0.198^{* * *} \\
(0.032)\end{array}$ & $\begin{array}{l}0.219^{* * *} \\
(0.013)\end{array}$ & $\begin{array}{l}0.245^{* * *} \\
(0.024)\end{array}$ & $\begin{array}{l}0.196^{* * *} \\
(0.032)\end{array}$ & $\begin{array}{l}0.219^{* * *} \\
(0.014)\end{array}$ \\
\hline ELIG & $\begin{array}{c}0.0150 \\
(0.0115)\end{array}$ & $\begin{array}{l}0.0397^{* *} \\
(0.0199)\end{array}$ & $\begin{array}{l}-0.00520 \\
(0.0683)\end{array}$ & $\begin{array}{c}0.0146 \\
(0.0115)\end{array}$ & $\begin{array}{l}0.0399^{* *} \\
(0.0198)\end{array}$ & $\begin{array}{l}-0.00431 \\
(0.0680)\end{array}$ \\
\hline$R O Y \_R E V$ & $\begin{array}{l}-0.289^{* * *} \\
(0.0977)\end{array}$ & $\begin{array}{c}-0.356^{* * *} \\
(0.110)\end{array}$ & $\begin{array}{l}1.377^{* * *} \\
(0.426)\end{array}$ & $\begin{array}{l}-0.289^{* * *} \\
(0.0979)\end{array}$ & $\begin{array}{c}-0.354^{* * *} \\
(0.110)\end{array}$ & $\begin{array}{l}1.383^{* * *} \\
(0.426)\end{array}$ \\
\hline$G D P \_P C$ & $\begin{array}{l}-0.235^{* * *} \\
(0.0570)\end{array}$ & $\begin{array}{l}-0.255^{* * *} \\
(0.0670)\end{array}$ & $\begin{array}{l}0.962^{* * *} \\
(0.257)\end{array}$ & $\begin{array}{l}-0.236^{* * *} \\
(0.0571)\end{array}$ & $\begin{array}{l}-0.257^{* * *} \\
(0.0671)\end{array}$ & $\begin{array}{l}0.964^{* * *} \\
(0.257)\end{array}$ \\
\hline$P O P$ & $\begin{array}{l}-0.235^{* * *} \\
(0.0528)\end{array}$ & $\begin{array}{l}-0.218^{* * *} \\
(0.0730)\end{array}$ & $\begin{array}{l}0.844^{* * *} \\
(0.236)\end{array}$ & $\begin{array}{l}-0.237^{* * *} \\
(0.0527)\end{array}$ & $\begin{array}{l}-0.222^{* * *} \\
(0.0730)\end{array}$ & $\begin{array}{l}0.846^{* * *} \\
(0.235)\end{array}$ \\
\hline$F P M \_R E V$ & $\begin{array}{l}0.00869^{* * *} \\
(0.00322)\end{array}$ & $\begin{array}{l}0.00935^{* *} \\
(0.00395)\end{array}$ & $\begin{array}{l}-0.0274^{*} \\
(0.0157)\end{array}$ & $\begin{array}{l}0.00870^{* * * *} \\
(0.00322)\end{array}$ & $\begin{array}{l}0.00937^{* *} \\
(0.00395)\end{array}$ & $\begin{array}{l}-0.0276^{*} \\
(0.0157)\end{array}$ \\
\hline$A G R \_G D P$ & $\begin{array}{l}-0.0198^{* * *} \\
(0.00423)\end{array}$ & $\begin{array}{l}-0.0345^{* * *} \\
(0.00579)\end{array}$ & $\begin{array}{l}-0.0440^{* *} \\
(0.0173)\end{array}$ & $\begin{array}{l}-0.0198^{* * *} \\
(0.00424)\end{array}$ & $\begin{array}{l}-0.0347^{* * *} \\
(0.00580)\end{array}$ & $\begin{array}{l}-0.0436^{* *} \\
(0.0173)\end{array}$ \\
\hline$R E V_{-} G D P$ & $\begin{array}{l}-0.259^{* * *} \\
(0.0591)\end{array}$ & $\begin{array}{l}-0.295^{* * *} \\
(0.0692)\end{array}$ & $\begin{array}{l}1.052^{* * *} \\
(0.267)\end{array}$ & $\begin{array}{l}-0.259^{* * *} \\
(0.0593)\end{array}$ & $\begin{array}{l}-0.295^{* * *} \\
(0.0693)\end{array}$ & $\begin{array}{l}1.055^{* * *} \\
(0.267)\end{array}$ \\
\hline Constant & $\begin{array}{l}2.015^{* * *} \\
(0.489)\end{array}$ & $\begin{array}{l}1.954^{* * *} \\
(0.681)\end{array}$ & $\begin{array}{l}-7.914^{* * *} \\
-2.194\end{array}$ & $\begin{array}{l}2.075^{* * *} \\
(0.489)\end{array}$ & $\begin{array}{l}2.359^{* * *} \\
(0.678)\end{array}$ & $\begin{array}{l}-8.101^{* * *} \\
-2.187\end{array}$ \\
\hline Year dummies & Yes & Yes & Yes & Yes & Yes & Yes \\
\hline Political party dummies & No & No & No & Yes & Yes & Yes \\
\hline observations & 19291 & 19283 & 18916 & 19246 & 19238 & 18872 \\
\hline panel observations & 4843 & 4842 & 4812 & 4833 & 4832 & 4801 \\
\hline chi2 & 309.2 & 310.6 & 367.1 & 3175 & 469.1 & 437.1 \\
\hline sig2 & 0.0126 & 0.0309 & 0.260 & 0.0125 & 0.0307 & 0.260 \\
\hline
\end{tabular}

$\left({ }^{* * *}\right)$ Significant at $1 \% ;\left(^{* *}\right)$ significant at 5\%; $\left(^{*}\right)$ significant at $10 \%$.

Robust standard deviations in parenthesis. 
Table 5: Results for expenses: Health, Education, Energy and Housing

\begin{tabular}{|c|c|c|c|c|c|c|c|c|}
\hline & \multicolumn{8}{|c|}{ Dependent Variables, relative to budgetary expenses, in log. } \\
\hline & Health & Education & Energy & Housing & Health & Education & Energy & Housing \\
\hline Independent variables (log) & (1.a) & (2.a) & (3.a) & (4.a) & (1.b) & (2.b) & (3.b) & (4.b) \\
\hline \multirow[t]{2}{*}{ lag_1 } & $0.337^{* * *}$ & $0.206^{* * *}$ & $0.104^{* * *}$ & $0.320^{* * *}$ & $0.336^{* * *}$ & $0.206^{* * *}$ & $0.107^{* * *}$ & $0.319^{* * *}$ \\
\hline & $(0.030)$ & $(0.044)$ & $(0.032)$ & $(0.024)$ & $(0.030)$ & $(0.044)$ & $(0.032)$ & $(0.024)$ \\
\hline \multirow[t]{2}{*}{ ELIG } & $0.122^{*}$ & 0.0117 & -0.227 & 0.0882 & $0.122^{*}$ & 0.0112 & -0.234 & 0.0872 \\
\hline & $(0.0693)$ & $(0.0343)$ & $(0.222)$ & $(0.0820)$ & $(0.0691)$ & $(0.0341)$ & $(0.223)$ & $(0.0814)$ \\
\hline \multirow[t]{2}{*}{$R O Y \_R E V$} & $0.193^{*}$ & -0.00298 & 3.629 & 0.228 & $0.192^{*}$ & -0.00371 & 4.130 & 0.228 \\
\hline & $(0.103)$ & $(0.0602)$ & -3.684 & $(0.190)$ & $(0.103)$ & $(0.0612)$ & -3.758 & $(0.190)$ \\
\hline \multirow[t]{2}{*}{$G D P \_P C$} & $0.176^{* * *}$ & 0.00594 & $-0.812^{* *}$ & $0.210^{* *}$ & $0.177^{* * *}$ & 0.00624 & $-0.811^{* *}$ & $0.209^{* *}$ \\
\hline & $(0.0323)$ & $(0.0215)$ & $(0.335)$ & $(0.0986)$ & $(0.0321)$ & $(0.0217)$ & $(0.337)$ & $(0.0986)$ \\
\hline \multirow[t]{2}{*}{$P O P$} & 0.0400 & $0.0686^{*}$ & -0.675 & -0.00802 & 0.0301 & $0.0680^{*}$ & -0.651 & 0.000264 \\
\hline & $(0.0598)$ & $(0.0396)$ & $(0.701)$ & $(0.153)$ & $(0.0591)$ & $(0.0400)$ & $(0.706)$ & $(0.154)$ \\
\hline \multirow[t]{2}{*}{$F P M \_R E V$} & $-0.0114^{*}$ & $0.0187^{* *}$ & $-0.111^{*}$ & 0.00760 & $-0.0115^{*}$ & $0.0187^{* *}$ & $-0.114^{*}$ & 0.00755 \\
\hline & $(0.00679)$ & $(0.00857)$ & $(0.0610)$ & $(0.0163)$ & $(0.00678)$ & $(0.00857)$ & $(0.0611)$ & $(0.0163)$ \\
\hline \multirow[t]{2}{*}{$A G R \_G D P$} & -0.00955 & $0.0187^{* * *}$ & $-0.492^{* * *}$ & -0.0122 & -0.00957 & $0.0185^{* * *}$ & $-0.483^{* * * *}$ & -0.0118 \\
\hline & $(0.0113)$ & $(0.00625)$ & $(0.146)$ & $(0.0229)$ & $(0.0113)$ & $(0.00625)$ & $(0.146)$ & $(0.0229)$ \\
\hline \multirow[t]{2}{*}{$R E V_{-} G D P$} & $0.110^{* * *}$ & $-0.0562^{* * *}$ & $-0.655^{* *}$ & $0.208^{* *}$ & $0.110^{* * *}$ & $-0.0559^{* * *}$ & $-0.660^{* *}$ & $0.207^{* *}$ \\
\hline & $(0.0297)$ & $(0.0198)$ & $(0.297)$ & $(0.0942)$ & $(0.0295)$ & $(0.0199)$ & $(0.299)$ & $(0.0942)$ \\
\hline Year dummies & Yes & Yes & Yes & Yes & Yes & Yes & Yes & Yes \\
\hline Political party dummy & No & No & No & No & Yes & Yes & Yes & Yes \\
\hline \multirow[t]{2}{*}{ Constant } & -0.511 & $-0.758^{* *}$ & 6.561 & -0.118 & -0.905 & $-0.730^{*}$ & 6.337 & 0.534 \\
\hline & $(0.568)$ & $(0.374)$ & -6.467 & -1.442 & $(0.600)$ & $(0.379)$ & -6.582 & -1.407 \\
\hline Observations & 19189 & 19256 & 3078 & 18324 & 19144 & 19211 & 3070 & 18284 \\
\hline panel observations & 4832 & 4840 & 1371 & 4742 & 4822 & 4830 & 1369 & 4733 \\
\hline chi2 & 0.0814 & 0.0431 & 1.303 & 0.345 & 0.0813 & 0.0432 & 1.308 & 0.344 \\
\hline sig2 & 209.4 & 343.5 & 92.84 & 219.1 & 270.7 & 382.0 & 5636 & 270.6 \\
\hline
\end{tabular}

$\left({ }^{* * *}\right)$ Significant at 1\%; $\left(^{* *}\right)$ significant at 5\%; $\left(^{*}\right)$ significant at $10 \%$. Robust standard deviations in parenthesis. 
Tables 4 and 5 exhibit the results of equation (2). Table 4 summarizes the estimated coefficients for cost, personal and investment. The specifications labeled as (a) do not control for political party while the specifications (b) add dummies for the political party in charge that year. Results show that royalties reduced both the relative cost and personal expense in the budget of eligible municipalities: the elasticities of such variables in relation to royalty-revenues ratio are -0.29 and -0.35 , respectively. Despite the small magnitude, the effect is statistically significant. Meanwhile, the impact of windfall revenues on investment is positive, with elasticity around +1.38 .

Both results suggest evidence that municipalities are respecting the guidelines from the Petroleum Law.

However, eligible municipalities spend on average more on cost (statistically non-significant), on personal (statistically significant) than non-eligible municipalities. Also eligible municipalities spend less on investment (statistically non-significant) than non-eligible municipalities.

The signals of control variables present the expected signs. Richer and more populous localities tend to invest a higher share of their budget and to spend a lower portion in ordinary expenses. Moreover, municipalities highly dependent on federal funds (FPM) spend a higher portion of their budget in cost and personal.

Regarding specific items of the budget (Table 5), results are no significant. Only the share of health expenses have increased in the budget of eligible municipalities as consequence of windfall revenues, but the estimative is significant only at $10 \%$-level. Besides, eligible municipalities spend on average more on health than non-eligible municipalities. Finally, Municipalities did not increase the share of the budget allocated to Education, Energy and Housing.

\section{Conclusions}

The Federal Government provides a subset of Brazilian municipalities with a financial compensation in the form of a percentage of collected petroleum rents (royalties) in order to offset possible deleterious effects of oil and gas production over their economies.

Federal Law 9478 of 1997 (the so-called "Petroleum Law) is the starting point of the new regulatory framework for the oil market, securing a significant portion of royalties for the municipalities affected by the oil and gas upstream sector.

The purpose of this paper is to investigate the effects of large fiscal windfalls operating through the government. More precisely, we evaluate whether municipalities eligible to receive royalties exhibit different fiscal behavior when compared to noneligible ones.

The results indicate that windfall oil rents reduce fiscal effort, increase investment, and do not affect health, education, energy and housing spending.

Regarding the negative effects on fiscal effort, we can argue that in anticipation of revenue windfalls some municipalities must have decided to exploit less the potential of their existing taxes. Higher taxes are hard to explain to voters but not higher transfers. 
Regarding the positive effects on investment, they do not give support to the political-economy models. It seems in fact that the law has been effective in the sense of compensating future generations.

Finally, this study has some shortages to be overcome and several further developments are possible. A natural question emerging from this study is the quality of the increased investment we have detected. We also have tried to address the problem of endogeneity using a specific estimator, but other methods are also possible. Nevertheless, the assessment of the consequences of Petroleum Law (and more specifically the windfall revenues) on local finance is still in the beginning and this paper aims to provide new lights to the debate, which is getting more and more important due to the recent pre-salt discoveries.

\section{References}

Arellano, M.; Bond, S. 1991. Some Tests of Specification for Panel Data: Monte Carlo Evidence and an Application to Employment Equations. Review of Economic Studies. vol. 58.

Battese, G. 1992. Frontier production functions and technical efficiency: a survey of empirical applications in agricultural economics. Agricultural Economics. v.7. p.185-208.

Blanco, F.A. 1998. Disparidades interregionais. Capacidade de Obtenção de Recursos Tributários. Esforço Fiscal e Gasto Público no Federalismo Brasileiro. XX Prêmio BNDES de Dissertações de Mestrado. Rio de Janeiro: BNDES. 1998.

Bregman, D. 2007. Formação. Distribuição e aplicação de royalties de recursos naturais: $O$ caso do petróleo no Brasil. Dissertação de mestrado em Economia. Instituto de economia. Rio de Janeiro. Universidade Federal do Rio de Janeiro. 2007.

Caselli, F. 2007. Power struggles and the natural resource curse. Unpublished London School of Economics.

Cossio, F.A.B.; Carvalho, L.M. 2001. Os efeitos expansivos das transferências intergovernamentais e transbordamentos espaciais de despesas públicas: evidências para os municípios brasileiros. Pesquisa e Planejamento Econômico 31(1), IPEA, Rio de Janeiro, pp. 75-124.

Costa Nova, L., 2005. Análise do impacto social de receitas provenientes de royalties do petróleo em municípios do estado da Bahia. Dissertação de Mestrado, Universidade de Brasília, 2005.

Dahby. B. 2009. The Marginal Cost of Public Funds and the Flypaper Effect. Working paper. University of Alberta. Canadá. 
Dixit, A.; Londengran, J. 1998. "Fiscal federalism and redistributive politics”. Journal of Public Economics 68 (2), 153-180.

Friedmann, R.; Montalvão, E. 2003. Compensações financeiras pela exploração de recursos minerais da União: política atual e recomendações de reforma. Estudo no. 29, Consultoria Legislativa do Senado Federal.

Gamkhar. S. and A. Shah. 2007. The Impact of Intergovernmental Transfers: A Synthesis of the Conceptual and Empirical Literature. In R. Boadway and A. Shah (eds.) Intergovernmental Fiscal Transfers: Principles and Practice. The World Bank. Washington. DC.

Hartwick, J.M., 1977. Intergenerational Equity and the Investing of Rents from Exhaustible Resources. American Economic Review 67, nº 5, dez/1977, 972-974.

Inman, R. P. 2008. The Flypaper Effect. NBER Working Paper No. w14579.

Kennedy, S. and Robbins, J. 2001. The role of fiscal rules in determining fiscal performance, Department of Finance Working Paper 2001-16, Canada.

Leal, J.A.A., Serra, R.V., 2002. Notas sobre os Fundamentos Econômicos da Distribuição Espacial dos Royalties Petrolíferos no Brasil. Anais do $X X X$ Encontro Nacional de Economia (ANPEC). Nova Friburgo, RJ, 2002.

Navarro, C. A. S. Royalties do petróleo. estudo do caso de Campos dos Goytacazes. Dissertação (Mestrado em Economia Empresarial). Rio de Janeiro. Universidade Candido Mendes. 2007.

Persson, T., Tabellini, J. 1996. "Federal fiscal constitutions: risk sharing and moral hazard”. Econometrica, 64, n. 3, pp. 623-646.

Reis, E. J.. Blanco. F. A. Capacidade tributária dos estados brasileiros 1970/90. Economia Brasileira em Perspectiva - 1996. Rio de Janeiro: IPEA. v. 1. p. 325-353. 1996.

Reis, E. J.. Blanco. F. A. Capacidade tributária dos estados brasileiros 1970/90. Economia Brasileira em Perspectiva - 1996. Rio de Janeiro: IPEA. v. 1. p. 325-353. 1996.

Ribeiro, E. P. 2005. Capacidade e Esforço Tributário no Rio Grande do Sul: O caso dos municípios. Perspectiva Econômica online. Disponível em: http://www.perspectivaeconomica.unisinos.br/pdfs/36.pdf. Acesso em 20.abr.09.

Ribeiro, E. P; Shikida, C. D.. Existe trade-off entre receitas próprias e transferências? O caso dos municípios mineiros. In Anais do IX Encontro de Economia Mineira. Diamantina. CEDEPLAR/UFMG. 2000.

Robinson, J.A., Torvik, R. and Verdier, T. 2002. Political foundations of the resource curse. CEPR Discussion Paper no. 3422.

Serra, R.V. 2003. Desdobramento Espacial da Exploração e Produção de Petróleo no Brasil: em busca de um nexo para a distribuição dos royalties entre os Municípios. Belo Horizonte: X ENANPUR, 2003. 
Shah, A . 1994. The Reform of Intergovernmental fiscal relations in developing and emerging market economies. Policy and Research Series no.23. The World Bank. 